\title{
Exhaled nitric oxide and clinical phenotypes of childhood asthma
}

Bruno Mahut ${ }^{1,2,3}$, Séverine Peyrard ${ }^{5}$ and Christophe Delclaux ${ }^{2,3,4,5^{*}}$

\begin{abstract}
Whether exhaled NO helps to identify a specific phenotype of asthmatic patients remains debated. Our aims were to evaluate whether exhaled $\mathrm{NO}\left(\mathrm{FENO}_{0.05}\right)$ is independently associated (1) with underlying pathophysiological characteristics of asthma such as airway tone (bronchodilator response) and airway inflammation (inhaled corticosteroid [ICS]-dependant inflammation), and (2) with clinical phenotypes of asthma.

We performed multivariate (exhaled $\mathrm{NO}$ as dependent variable) and k-means cluster analyses in a population of 169 asthmatic children (age \pm SD: $10.5 \pm 2.6$ years) recruited in a monocenter cohort that was characterized in a cross-sectional design using 28 parameters describing potentially different asthma domains: atopy, environment (tobacco), control, exacerbations, treatment (inhaled corticosteroid and long-acting bronchodilator agonist), and lung function (airway architecture and tone).

Two subject-related characteristics (height and atopy) and two disease-related characteristics (bronchodilator response and ICS dose $>200 \mu \mathrm{g} / \mathrm{d}$ ) explained 36\% of exhaled NO variance. Nine domains were isolated using principal component analysis. Four clusters were further identified: cluster 1 (47\%): boys, unexposed to tobacco, with well-controlled asthma; cluster 2 (26\%): girls, unexposed to tobacco, with well-controlled asthma; cluster 3 (6\%): girls or boys, unexposed to tobacco, with uncontrolled asthma associated with increased airway tone, and cluster 4 (21\%): girls or boys, exposed to parental smoking, with small airway to lung size ratio and uncontrolled asthma. $\mathrm{FENO}_{0.05}$ was not different in these four clusters.

In conclusion, $\mathrm{FENO}_{0.05}$ is independently linked to two pathophysiological characteristics of asthma (ICS-dependant inflammation and bronchomotor tone) but does not help to identify a clinically relevant phenotype of asthmatic children.
\end{abstract}

\section{Introduction}

Numerous studies have evaluated exhaled nitric oxide (NO) correlates in asthma. For instance, exhaled NO fraction $\left(\mathrm{FE}_{\mathrm{NO}}\right)$ has been linked to atopy rather than to asthma per se which could be due to the underlying relationship between $\mathrm{FE}_{\mathrm{NO}}$ and eosinophilic inflammation of airways[1]. We and others have emphasized that $\mathrm{FE}_{\mathrm{NO}}$ is also linked to other intrinsic dimensions of asthma such as airway reactivity/tone [2,3] and remodeling of airways $[1,4]$. All these relationships may explain the complex and still debated relationship between exhaled NO and asthma control/severity[4-6]. Moreover, extrinsic factors also affect $\mathrm{FE}_{\mathrm{NO}}$ such as tobacco exposure and asthma treatment[6,7]. Finally, the epithelial

\footnotetext{
* Correspondence: christophe.delclaux@egp.aphp.fr

${ }^{2}$ Assistance Publique-Hôpitaux de Paris; Hôpital Européen Georges

Pompidou; Service de Physiologie - Clinique de la Dyspnée, Paris, France

Full list of author information is available at the end of the article
}

surface of airways, which is linked to the height of the subject and possibly to sex, also affects exhaled NO[8]. Despite this considerable background, the usefulness of its assessment in clinical practice remains debated because of its multidimensional nature, precisely. Furthermore, all these intrinsic and extrinsic exhaled NO modifiers seem to contribute for a minor part of exhaled NO variance,[6] which constitutes a main limitation.

The recent study of Dweik and colleagues has shown that $\mathrm{FE}_{\mathrm{NO}}$ may define an asthma phenotype. They demonstrated that their high $\mathrm{FE}_{\mathrm{NO}}$ phenotype $\left(\mathrm{FE}_{\mathrm{NO} 0.05}>35\right.$ $\mathrm{ppb})$ was characterized by greatest airway reactivity, airflow limitation, hyperinflation, sputum eosinophilia and levels of symptoms[9]. Nevertheless, $\mathrm{FE}_{\mathrm{NO}}$ levels were similar among patients with severe and non-severe asthma in this latter study. One may hypothesize that the establishment of one or several relationships between $\mathrm{FE}_{\mathrm{NO}}$ and

\section{Biomed Central}

(c) 2011 Mahut et al; licensee BioMed Central Ltd. This is an Open Access article distributed under the terms of the Creative Commons Attribution License (http://creativecommons.org/licenses/by/2.0), which permits unrestricted use, distribution, and reproduction in any medium, provided the original work is properly cited. 
asthma characteristics (either clinical or physiological) is not sufficient to demonstrate that exhaled NO identifies a specific phenotype with clinical relevance, accordingly to a more focused definition of phenotype[10].

The aims of our study were therefore (1) to evaluate the strength of the relationships between exhaled NO and physiopathological asthma characteristics, and (2) to assess whether a specific clinical phenotype can be isolated using exhaled NO measurement. For that purpose, we used two different statistical approaches. The first approach determined the clinical and physiological correlates of exhaled $\mathrm{NO}$, and the degree of $\mathrm{FE}_{\mathrm{NO}}$ variance explained by the correlates. The second approach used a more complex statistical tool, namely cluster analysis, which describes the dimensions of disease without the need for arbitrary a priori assumptions about classification, and was specifically designed to test the hypothesis that $\mathrm{FE}_{\mathrm{NO}}$ is associated with a phenotype of childhood asthma.

\section{Methods \\ Design of the study \\ La Berma Cohort}

This single centre cohort conducted in a secondary care out-hospital clinic enrolls asthmatic children since 1997. Since 2008, exhaled NO and clinical events were recorded. Levels of asthma control were systematically assessed using only two levels of GINA guidelines during past three months:[11] controlled versus partially/ uncontrolled asthma (omitting lung function since PFT were obtained without treatment). Severe exacerbations, according to ATS/ERS definition, [12] and the number of days (1) with symptoms (GINA guidelines) [11] and (2) with systemic steroid were specifically recorded. This cohort has been declared to our regulatory agency for computer data collection (Commission Nationale Informatique et Libertés, $\mathrm{n}^{\circ} 1408710$ ), and approval from the Ethics Committee of French learned Society of Pulmonology - SPLF was obtained (CEPRO 2009/019). All children and parents were informed of the prospective recording of clinical and physiological data.

\section{Patients and criteria of selection from the cohort}

We selected a sample of children, meeting the criteria of clinical (episodic symptoms of airflow obstruction with excluded alternative diagnoses) and functional (documented bronchodilator response based on $\mathrm{FEV}_{1}$ or sRaw)[13] diagnosis of asthma and who satisfied a full description of their asthma: these 28 variables (see Table 1) are categorized as (1) anthropometrics, (2) past history, (3) parental smoking (more than 5 cigarettes per day), level of control, treatment, and (3) pulmonary function. All data were those specifically determined at the time of only one visit, corresponding to routine evaluation in France. These variables allowed the assessment
Table 1 Clinical and physiological characteristics of the asthmatic children

\begin{tabular}{|c|c|c|}
\hline Characteristics & \multicolumn{2}{|c|}{$\mathrm{N}=169$} \\
\hline Sex (male, \%) & \multicolumn{2}{|c|}{$104(61 \%)$} \\
\hline age, years & \multicolumn{2}{|c|}{$10.5 \pm 2.6$} \\
\hline height, cm & \multicolumn{2}{|c|}{$142 \pm 15$} \\
\hline weight, kg & \multicolumn{2}{|c|}{$38 \pm 15$} \\
\hline $\mathrm{BMI}, \mathrm{kg} \cdot \mathrm{m}^{-2}$ & \multicolumn{2}{|c|}{$18.0 \pm 3.5$} \\
\hline \multicolumn{3}{|l|}{ Atopic status (skin prick test) } \\
\hline negative & \multicolumn{2}{|c|}{$27(16 \%)$} \\
\hline 1 positive & \multicolumn{2}{|c|}{$41(24 \%)$} \\
\hline$>1$ positive & \multicolumn{2}{|c|}{$101(60 \%)$} \\
\hline \multicolumn{3}{|l|}{ Tobacco exposure, n (\%) } \\
\hline maternal & \multicolumn{2}{|c|}{$25(15 \%)$} \\
\hline paternal & \multicolumn{2}{|c|}{$24(14 \%)$} \\
\hline paternal and maternal & \multicolumn{2}{|c|}{$36(21 \%)$} \\
\hline \multicolumn{3}{|l|}{ Clinical events within past 3 months } \\
\hline controlled, n (\%) & \multicolumn{2}{|c|}{$56(33 \%)$} \\
\hline partially or uncontrolled & \multicolumn{2}{|c|}{$113(67 \%)$} \\
\hline number of days with symptoms, median $[\mathrm{IQ}]$ & \multicolumn{2}{|c|}{$4[0-12]$} \\
\hline severe exacerbation & \multicolumn{2}{|c|}{$42(31 \%)$} \\
\hline $\begin{array}{l}\text { number of days with systemic steroid, median } \\
{[\mathrm{IQ}]}\end{array}$ & \multicolumn{2}{|c|}{$0[0-2]$} \\
\hline \multicolumn{3}{|l|}{ Treatment } \\
\hline beta-agonist on demand, n (\%) & \multicolumn{2}{|c|}{$82(48 \%)$} \\
\hline low ICS dose, $\mathrm{n}(\%) ;$ mean \pm SD dose, $\mu \mathrm{g}$ & \multicolumn{2}{|c|}{$45(27 \%) ; 154 \pm 51$} \\
\hline medium ICS dose, $\mathrm{n}(\%)$; mean \pm SD dose, $\mu \mathrm{g}$ & \multicolumn{2}{|c|}{$28(17 \%) ; 357 \pm 50$} \\
\hline high ICS dose, $\mathrm{n}(\%) ;$ mean \pm SD dose, $\mu \mathrm{g}$ & \multicolumn{2}{|c|}{$14(8 \%) ; 707 \pm 154$} \\
\hline LABA, n (\%) & \multicolumn{2}{|c|}{$73(43 \%)$} \\
\hline Pulmonary function tests & Pre BD & Post BD \\
\hline sRaw, \% predicted & $204 \pm 45$ & $126 \pm 30$ \\
\hline $\mathrm{FEV}_{1}, \%$ predicted & $97 \pm 13$ & $107 \pm 12$ \\
\hline $\mathrm{FEV}_{1} / \mathrm{FVC}, \%$ & $78 \pm 8$ & $84 \pm 6$ \\
\hline FVC, \% predicted & $105 \pm 13$ & $108 \pm 12$ \\
\hline $\mathrm{FEF}_{75-25 \%} \%$ predicted & $71 \pm 19$ & $91 \pm 20$ \\
\hline $\mathrm{FEF}_{50 \%} \%$ predicted & $71 \pm 18$ & $91 \pm 19$ \\
\hline TLC, \% predicted & $104 \pm 11$ & $103 \pm 10$ \\
\hline FRC, $\%$ predicted & $103 \pm 17$ & $100 \pm 15$ \\
\hline RV, \% predicted & $107 \pm 28$ & $93 \pm 22$ \\
\hline $\mathrm{RV} / \mathrm{TLC}$ & $\begin{array}{l}0.25 \pm \\
0.06\end{array}$ & $\begin{array}{l}0.22 \pm \\
0.05\end{array}$ \\
\hline $\mathrm{FEF}_{50 \%} / \mathrm{TLC}$ & $\begin{array}{l}0.71 \pm \\
0.14\end{array}$ & $\begin{array}{c}0.80 \pm \\
0.18\end{array}$ \\
\hline $\mathrm{FENO}_{0.05} \mathrm{ppb}$, median $[\mathrm{IQ}]$ & 29 [15-48] & \\
\hline
\end{tabular}

BD: denotes bronchodilator

Results are provided as mean \pm SD or median $\left[25^{\text {th }}-75^{\text {th }}\right.$ percentiles: IQ] or absolute number with percent age (\%).

of three domains of asthma severity: level of current prescribed treatment, level of current baseline control of asthma and immediate past burden of asthma exacerbations, accordingly to Bush and Saglani[14]. The population included in the current retrospective, post hoc, database design study overlaps to some extent with the populations of children published previously[2,6,15-17]. 
Exhaled NO ( $\left.\mathrm{FE}_{\mathrm{NO}}, 0.05\right)$

Exhaled NO was measured online, using the Nitric Oxide Analyzer (NIOX; Aerocrine AB; Solna, Sweden: measurement at a constant $50 \mathrm{~mL} / \mathrm{s}$ expiratory flow rate: $\left.\mathrm{FE}_{\mathrm{NO}, 0.05}\right)$. Measurements were performed according to the ERS/ATS guidelines before pulmonary function tests[18].

\section{Pulmonary function tests (PFT)}

All PFT were performed without inhaled treatment (bronchodilator or LABA/ICS association) on the day of the measurement, by the same operator (BM). Spirometry and plethysmographic measurement of specific airway resistance and thoracic gas volume were performed according to international guidelines and as previously described $[13,15,19]$. The bronchodilator response to salbutamol $400 \mu \mathrm{g}$ : (post minus baseline)/baseline $\mathrm{FEV}_{1}$ was systematically assessed. Reference values were based on equations edited by Zapletal,[20] as commonly done in Europe[21].

\section{Statistical analysis \\ First approach}

Potential explanatory variable were: age, gender, height, atopy, tobacco exposure, control, treatment and pulmonary function tests. The association between the different explanatory variables and $\mathrm{FE}_{\mathrm{NO}}$ was examined in a multiple linear regression model using the procedure for general linear models with log-transformed $\mathrm{FE}_{\mathrm{NO}}$ values as the dependent variable. The multivariate analysis was performed with a backward selection method and variables with $\mathrm{P}$ values of less than 0.05 were retained in the $\mathrm{FE}_{\mathrm{NO}}$ model.

\section{Second approach}

We used the same approach than Haldar and colleagues [22]. Briefly, a cluster analysis methodology was applied to define homogeneous groups of patients. Principal component analysis (PCA) is a mathematical procedure that uses an orthogonal transformation to convert a set of observations of possibly correlated variables into a set of values of uncorrelated variables called principal components. The number of principal components is usually less than the number of original variables (data reduction). To obtain reliable results, the minimal number of subjects providing usable data for the analysis should be five times the number of variables being analyzed $(28 \times$ $5=140$ ). This transformation is defined in such a way that the first principal component has as high a variance as possible, and each succeeding component in turn has the highest variance possible under the constraint that it be orthogonal to (uncorrelated with) the preceding components. Then we requested a rotation of the resulting factors which follows completion of the analysis of the data[23]. It has been shown that the relaxed solution of $k$-means clustering, a common method of cluster analysis, [24] specified by the cluster indicators, is given by the PCA principal components, and thus PCA facilitates $k$-means clustering to find near-optimal solutions[25]. Cluster analysis allows the partitioning of data into meaningful subgroups (phenotypes), when the number of subgroups and other information about their composition may be unknown. We hypothesised that $\mathrm{FE}_{\mathrm{NO}}$ measurement could be associated with one of these subgroups of asthmatic children. First, variables for the cluster analysis were selected using a principal component analysis (PCA). When considering variable selection for the cluster analysis, our aims were (1) to choose variables that were measured in clinical practice and contributed to the clinical evaluation of asthma, and to avoid choosing different variables that were representative of the same aspect of the disease as this would introduce further bias when the cluster analysis was performed. We thus performed PCA of our 28 commonly measured clinical variables. Orthogonal varimax rotation was performed and the results are summarized in table 2. To avoid weighting the analysis, we selected only one parameter that was representative of each factor. Two additional variables were also included (see Table 2 legend). Then, a uniform cluster analysis methodology was applied accordingly to Haldar and colleagues (dendrogram for estimation of the number of likely clusters that was further prespecified in a k-means cluster analysis)[22]. Finally, characteristics of clusters were compared using analysis of variance for continuous variables or Kruskal Wallis Rank test (non normal values) and $\chi 2$ test for proportions. Statistical analyses were performed using MedCalc 11.3.8 (Mariakerke, Belgium) and OpenStat (version 5) softwares.

\section{Results}

Between December 1, 2008 and April 14, 2010, 1001 NO measurements were performed in 592 asthmatic children (clinical diagnose) of which 398 had a positive bronchodilator response in their history. Of these 398 subjects, 169 met the criteria for inclusion in the cluster analysis (all the children fulfilling inclusion criteria were included). Non inclusion criteria were the absence of recent skin pricks test $(n=62)$, the absence of bronchodilator test on the day of visit (absence of treatment withdrawal, $\mathrm{n}=130)$ and miscellaneous $(\mathrm{n}=37)$. Table 1 shows the characteristics of the 169 asthmatic children.

\section{First approach}

In univariate analysis, $\mathrm{FE}_{\mathrm{NO}}$ was more elevated in atopic than in non atopic children (35[19-57] pbb versus 12 [9-16] ppb, p < 0.001), less elevated in controlled children (20 [13 - 37] ppb versus 34 [16-57] ppb, p = 0.018) 
Table 2 Orthogonal varimax rotation results

\begin{tabular}{|c|c|c|c|c|c|c|c|c|c|}
\hline \multirow[t]{2}{*}{28 variables } & \multicolumn{9}{|c|}{ factors } \\
\hline & 1 & 2 & 3 & 4 & 5 & 6 & 7 & 8 & 9 \\
\hline \multicolumn{10}{|l|}{ Clinical } \\
\hline gender & & & & & & & & -0.765 & \\
\hline age & & -0.879 & & & & & & & \\
\hline height & & -0.889 & & & & & & & \\
\hline weight & & -0.905 & & & & & & & \\
\hline BMI & & -0.751 & & & & & & & \\
\hline early wheezing ( $<2$ years) & & & & & -0.339 & & 0.565 & & -0.368 \\
\hline atopy (positive SPT) & & & & & 0.800 & & & & \\
\hline parental smoking & & & & & & & & & 0.764 \\
\hline \multicolumn{10}{|l|}{ Treatment } \\
\hline LABA & & & 0.840 & & & & & & \\
\hline ICS treatment & & & 0.872 & & & & & & \\
\hline ICS dose & & & 0.898 & & & & & & \\
\hline ICS dose $>200 \mu \mathrm{g} / \mathrm{d}$ & & & 0.814 & & & & & & \\
\hline \multicolumn{10}{|l|}{ Clinical events } \\
\hline partially or uncontrolled & & & & 0.439 & & & 0.626 & & \\
\hline days with symptoms & & & & 0.089 & & & 0.777 & & \\
\hline exacerbation & & & & 0.942 & & & 0.054 & & \\
\hline days with oral steroid & & & & 0.940 & & & 0.085 & & \\
\hline \multicolumn{10}{|l|}{ Baseline PFT values } \\
\hline $\mathrm{FEV}_{1}$ & & & & & & 0.843 & & & \\
\hline FEV1/FVC & 0.843 & & & & & & & & \\
\hline sRaw & -0.609 & & & & & & & & \\
\hline $\mathrm{RV} / \mathrm{TLC}$ & & 0.645 & & & & 0.454 & & & \\
\hline $\mathrm{FEF}_{50 \%} / \mathrm{TLC}$ & 0.834 & & & & & & & -0.050 & \\
\hline \multicolumn{10}{|l|}{ Post bronchodilator PFT values } \\
\hline $\mathrm{FEV}_{1}$ & & & & & & 0.885 & & & \\
\hline FEV1/FVC & 0.757 & & & & & & & & \\
\hline sRaw & -0.391 & & & & & & & & \\
\hline $\mathrm{RV} / \mathrm{TLC}$ & & 0.664 & & & & & & & \\
\hline $\mathrm{FEF}_{50 \%} / \mathrm{TLC}$ & 0.797 & & & & & & & 0.286 & \\
\hline $\mathrm{FEV}_{1}$ response to $\mathrm{BD} \%$ & -0.569 & & & & 0.397 & & & 0.392 & \\
\hline Exhaled NO & -0.061 & -0.132 & -0.119 & -0.059 & 0.789 & -0.149 & 0.064 & 0.030 & 0.076 \\
\hline
\end{tabular}

PFT: denotes pulmonary function tests

All results for exhaled NO are shown in italic for information.

Factor analysis (PCA in our study) is based on the procedure for obtaining a new set of uncorrelated (orthogonal) variables, usually fewer in number than the original set ( 9 instead of 28 in our study), that reproduces the co-variability observed among a set or original variables. Then we requested a rotation of the resulting factors which follows completion of the analysis of the data. The most common rotation performed is the Varimax rotation[23]. This tends to produce "simple structure", that is, factors which have very high (that are provided in the table) or very low (provided for exhaled NO) loadings for the original variables and thus simplifies the interpretation of the resulting factors.

and more elevated in children with ICS dose $\leq 200 \mu \mathrm{g} / \mathrm{d}$ (19 [13-34] versus 31 [16-57], $\mathrm{p}=0.031)$. $\mathrm{FE}_{\mathrm{NO}}$ correlated with height $(\mathrm{r}=0.29, \mathrm{p}<0.001)$, age $(\mathrm{r}=0.25, \mathrm{p}=$ 0.001), $\mathrm{FEV}_{1}(\mathrm{r}=0.18, \mathrm{p}=0.021)$ and bronchodilator response $(\mathrm{r}=0.26, \mathrm{p}<0.001)$. $\mathrm{FE}_{\mathrm{NO}}$ was not decreased by tobacco exposure in univariate analysis. The multivariate analysis demonstrated that 4 variables independently correlated with $\log \mathrm{FE}_{\mathrm{NO}}$ (model: $\mathrm{r}=0.60, \mathrm{p}<$ $0.001)$ : atopy $(\mathrm{r}=0.46, \mathrm{p}<0.001)$, height $(\mathrm{r}=0.29 \mathrm{p}<$ $0.001)$, bronchodilator response $(\mathrm{r}=0.26, \mathrm{p}=0.011)$ and ICS dose $>200 \mu \mathrm{g} / \mathrm{d}(\mathrm{r}=-0.17, \mathrm{p}=0.019)$. Age, control and forced expiratory flows did not independently contribute to $\mathrm{FE}_{\mathrm{NO}}$ variance.

\section{Second approach}

Orthogonal varimax rotation was performed and the results are summarized in table 2 . Based on the pattern of loading we identified the factors as being representative of:

Factor 1: airway obstruction due to increased airway tonus (and airway to lung size ratio)

Factor 2: anthropometrics 
Factor 3: treatment

Factor 4: severe exacerbation

Factor 5: atopy

Factor 6: $\mathrm{FEV}_{1}$ (airway remodeling)

Factor 7: symptoms

Factor 8: gender

Factor 9: tobacco smoke exposure

Communality of all variables was $>60 \%$ (excepting sRaw) and $74.8 \%$ of the total variance was explained by the factors (all factors had Eigenvalues $>1$ ). The KaiserMeyer-Olkin measure of sampling adequacy was 0.643 .

From this result we determined the 9 variables selected for cluster analyses (we favored continuous variables): gender, height, parental smoking, ICS dose, number of days with symptoms and requiring oral steroid, $\mathrm{FEV}_{1} / \mathrm{FVC}, \mathrm{FEV}_{1}$ post BD and exhaled NO. Two additional variables were selected (1) $\mathrm{FEF}_{50 \%}$ /TLC postBD (index of airway/lung size) and (2) bronchodilator response (index of airway tonus).

A four-cluster model best fitted the population dataset, which were the following (Table 3): Cluster 1 (47\%) described a subgroup of asthmatic boys, unexposed to tobacco, with well-controlled asthma, Cluster $2(26 \%)$ described a subgroup of girls, unexposed to tobacco, with well-controlled asthma (similar to Cluster 1, excepting gender), Cluster 3 (6\%) described a subgroup of girls or boys, unexposed to tobacco, with uncontrolled asthma associated with increased airway tone, and Cluster 4 (21\%) also described a subgroup of girls or boys, exposed to parental smoking (either father, mother or both), with small airway to lung size ratio and uncontrolled asthma. The only difference (related to gender) between Cluster 1 and 2 was their airway to lung size ratio ( $\mathrm{p}=0.016$, Fisher test).

\section{Discussion}

The main results of our study is the demonstration that single-flow rate exhaled $\mathrm{NO}\left(\mathrm{FENO}_{0.05}\right)$ is independently associated with two main asthma pathophysiological characteristics, namely airway inflammation and airway tone, but that $\mathrm{FENO}_{0.05}$ does not help to distinguish a relevant clinical phenotype of childhood asthma in a cross-sectional assessment.

\section{Design issues}

We specifically assessed different components of asthma control definition, such as symptoms and exacerbations because whether severe exacerbation constitutes the ultimate expression of loss of control and/or a more unpredictable even remains controversial[12,14]. Table 2 further showed that control and exacerbations were two different dimensions of asthma, which could be related to our pediatric population[14]. Only two levels of control were assessed (controlled versus partially/ uncontrolled patients) because the achievement of control is the main clinical issue. Our percentage of controlled children (33\%) is in accordance with a French cross-sectional study in childhood asthma[26]. Since a dose effect of ICS on exhaled NO can be demonstrated, [2] we used it as an indirect index of airway inflammation, which is an obvious short-cut inasmuch as the explained variance of $\mathrm{FE}_{\mathrm{NO}}$ by ICS is only $\sim 3 \%$ in our study. Sputum eosinophilia can be regarded as the gold standard measure of inflammation but is not routinely assessed in most centres. The recent study of Schleich and colleagues demonstrates that $\mathrm{FE}_{\mathrm{NO}}$ is able to identify a sputum eosinophil count $\geq 3 \%$ with reasonable accuracy and thresholds which vary according to dose of ICS[27]. Finally, we deliberately chose to add two variables in the cluster analyses, namely post-bronchodilator $\mathrm{FEF}_{50 \%} / \mathrm{TLC}$ and bronchodilator response. The former is an index of airway size/lung size[28]. We hypothesized that such an index, which has been linked to the risk of airway responsiveness,[29] may influence symptoms. The latter may also be an important pathophysiological characteristic of asthma associated with poor clinical outcomes in childhood asthma[30].

Four clusters were identified in our pediatric population. The first two clusters can be considered similar when excluding gender and corresponds to the most prevalent group of asthmatic children in an out-hospital specialized clinic $(73 \%, 123 / 169)$ with $75 / 123$ children having partially/uncontrolled asthma. The remaining two clusters $(27 \%, 46 / 169)$ were constituted of boys and girls with a more severe (or undertreated) disease (38/46 with partially/uncontrolled asthma, 20/46 with a recent exacerbation). Interestingly, these two clusters only differ by their underlying severity factors, namely increased airway tonus (cluster 3, 6\% of the population) and parental tobacco exposure while having small airway/lung size ratio (cluster $4,21 \%$ ). The prevalence of cluster 3 is similar to that of difficult-to-treat patients $(\sim 5 \%)$, and may also constitute an asthma phenotype characterized by increased airway tone and lability[14,30]. The fourth cluster segregates children exposed to passive smoking that have a more severe disease, which is in line with the results of a French cross-sectional study in 3431 children demonstrating that unacceptable asthma control was associated with passive exposure to parental tobacco smoke[26]. Overall, the phenotypes that have been identified by the cluster analysis can be a posteriori explained, which further validate the statistical approach to assess exhaled NO usefulness. It has to be emphasized that the degree of asthma control did not clearly differentiate the clusters in our study. Several explanations can be discussed. Firstly, our study deals with childhood asthma, this specific population is often partially controlled because some degree of exercise 
Table 3 Clinical and physiological characteristics according to the four clusters

\begin{tabular}{|c|c|c|c|c|c|}
\hline Characteristics & $\begin{array}{c}\text { Cluster } 1 \\
\mathrm{n}=79\end{array}$ & $\begin{array}{c}\text { Cluster } 2 \\
\mathrm{n}=44\end{array}$ & $\begin{array}{c}\text { Cluster } 3 \\
\mathrm{n}=11\end{array}$ & $\begin{array}{c}\text { Cluster } 4 \\
\mathrm{n}=35\end{array}$ & P value* \\
\hline Gender, girls/boys \# & $0 / 79$ & $44 / 0$ & $5 / 6$ & $16 / 19$ & $<0.001$ \\
\hline Age, years & $10.6 \pm 2.9$ & $11.0 \pm 2.6$ & $10.0 \pm 1.3$ & $10.0 \pm 2.3$ & 0.34 \\
\hline Height, $\mathrm{cm}^{\#}$ & $144 \pm 17$ & $143 \pm 14$ & $139 \pm 9$ & $139 \pm 14$ & 0.33 \\
\hline Weight, kg & $39 \pm 16$ & $38 \pm 16$ & $35 \pm 7$ & $35 \pm 13$ & 0.46 \\
\hline $\mathrm{BMl}, \mathrm{kg} \cdot \mathrm{m}^{-2}$ & $18.2 \pm 3.2$ & $18.0 \pm 4.2$ & $17.8 \pm 2.3$ & $17.7 \pm 3.4$ & 0.92 \\
\hline Early wheezing, $n$ & 33 & 19 & 4 & 12 & 0.86 \\
\hline Atopy, n (\%) & $67(85)$ & $39(89)$ & $8(73)$ & $28(80)$ & 0.55 \\
\hline Tobacco exposure, both \# & 0 & 0 & 1 & 35 & $<0.001$ \\
\hline maternal & 0 & 0 & 0 & 25 & $<0.001$ \\
\hline paternal & 0 & 0 & 1 & 23 & $<0.001$ \\
\hline $\mathrm{ICS}, \mathrm{n}(\%)$ & $37(47)$ & $25(57)$ & $5(45)$ & $20(57)$ & 0.62 \\
\hline ICS dose, BED $\mu \mathrm{g} / \mathrm{d}^{\#}$ & $135 \pm 208$ & $180 \pm 236$ & $149 \pm 199$ & $188 \pm 217$ & 0.57 \\
\hline LABA, n & $33(42)$ & $22(50)$ & $4(36)$ & $15(43)$ & 0.58 \\
\hline \multicolumn{6}{|l|}{ Clinical events } \\
\hline Partially or uncontrolled, $\mathrm{n}$ & $46(58)$ & $29(66)$ & $10(91)$ & $28(80)$ & 0.028 \\
\hline Days with symptoms ${ }^{\#}$ & $3[0-8]$ & $4[0-12]$ & $3[3-7]$ & 7 [3-15] & 0.045 \\
\hline With exacerbation, $\mathrm{n}$ & $16(20)$ & $6(14)$ & $6(55)$ & $14(41)$ & 0.006 \\
\hline Days with oral steroid \# & $0[0-0]$ & $0[0-0]$ & $3[0-3]$ & $0[0-3]$ & 0.021 \\
\hline \multicolumn{6}{|l|}{ Pulmonary function tests } \\
\hline \multicolumn{6}{|l|}{ Before bronchodilation } \\
\hline $\mathrm{FE}_{\mathrm{NO}}, \mathrm{ppb} \#$ & $25[14-45]$ & 34 [19-51] & 21 [9-49] & 30 [14-52] & 0.58 \\
\hline sRaw, \% pred & $201 \pm 40$ & $200 \pm 54$ & $211 \pm 37$ & $212 \pm 47$ & 0.68 \\
\hline $\mathrm{FEF}_{50 \%} / \mathrm{TLC}$ & $0.70 \pm 0.13$ & $0.74 \pm 0.13$ & $0.62 \pm 0.15$ & $0.69 \pm 0.14$ & 0.5 \\
\hline $\mathrm{FEV}_{1}, \%$ pred & $98 \pm 13$ & $100 \pm 13$ & $91 \pm 14$ & $97 \pm 14$ & 0.28 \\
\hline FVC, \% pred & $104 \pm 14$ & $106 \pm 13$ & $106 \pm 15$ & $106 \pm 12$ & 0.88 \\
\hline $\mathrm{FEV}_{1} / \mathrm{FVC}^{\#}$ & $78 \pm 8$ & $80 \pm 6$ & $74 \pm 8$ & $77 \pm 9$ & 0.41 \\
\hline $\mathrm{FEF}_{25-75 \%} \%$ pred & $74 \pm 18$ & $72 \pm 18$ & $59 \pm 19$ & $70 \pm 20$ & 0.1 \\
\hline TLC, \% pred & $105 \pm 12$ & $104 \pm 9$ & $103 \pm 12$ & $106 \pm 10$ & 0.32 \\
\hline FRC, \% pred & $103 \pm 17$ & $102 \pm 17$ & $101 \pm 22$ & $105 \pm 18$ & 0.22 \\
\hline RV, \% pred & $107 \pm 28$ & $104 \pm 27$ & $101 \pm 20$ & $115 \pm 32$ & 0.23 \\
\hline $\mathrm{RV} / \mathrm{TLC}$ & $0.24 \pm 0.06$ & $0.25 \pm 0.06$ & $0.24 \pm 0.04$ & $0.27 \pm 0.06$ & 0.14 \\
\hline \multicolumn{6}{|l|}{ After bronchodilation } \\
\hline sRaw, \% pred & $125 \pm 28$ & $127 \pm 31$ & $117 \pm 22$ & $133 \pm 34$ & 0.22 \\
\hline $\mathrm{FEF}_{50 \%} / \mathrm{TLC} \#$ & $0.78 \pm 0.17$ & $0.86 \pm 0.15$ & $0.80 \pm 0.22$ & $0.75 \pm 0.22$ & 0.025 \\
\hline $\mathrm{FEV}_{1}, \%$ pred $^{\#}$ & $107 \pm 12$ & $110 \pm 12$ & $105 \pm 14$ & $107 \pm 12$ & 0.47 \\
\hline FVC, \% pred & $107 \pm 13$ & $108 \pm 12$ & $107 \pm 14$ & $110 \pm 12$ & 0.69 \\
\hline $\mathrm{FEV}_{1} / \mathrm{FVC}, \%$ & $84 \pm 6$ & $86 \pm 4$ & $83 \pm 8$ & $82 \pm 7$ & 0.05 \\
\hline $\mathrm{FEF}_{25-75 \%} \%$ pred & $92 \pm 20$ & $95 \pm 16$ & $86 \pm 25$ & $84 \pm 21$ & 0.17 \\
\hline TLC, \% pred & $103 \pm 11$ & $102 \pm 9$ & $101 \pm 13$ & $104 \pm 10$ & 0.73 \\
\hline FRC, \% pred & $101 \pm 16$ & $100 \pm 14$ & $95 \pm 19$ & $101 \pm 13$ & 0.3 \\
\hline $\mathrm{RV}, \%$ pred & $95 \pm 22$ & $90 \pm 22$ & $91 \pm 25$ & $96 \pm 23$ & 0.78 \\
\hline $\mathrm{RV} / \mathrm{TLC}$ & $0.22 \pm 0.05$ & $0.22 \pm 0.05$ & $0.23 \pm 0.04$ & $0.23 \pm 0.05$ & 0.6 \\
\hline Bronchodilator response, \% \# & $8[5-12]$ & $10[5-17]$ & $15[9-20]$ & 8 [3-16] & 0.036 \\
\hline
\end{tabular}

\# : variables included in the cluster analysis

* : Comparison between clusters using analysis of variance for continuous variables or Kruskal Wallis Rank test (non normal values) and $\chi^{2}$ test for proportions. Significance values for variables included in the cluster analysis are a product of the cluster algorithm and are provided for illustrative purposes only. Results are provided as mean \pm SD or median $\left[25^{\text {th }}-75^{\text {th }}\right.$ percentiles] or absolute number with percent age (\%). 
limitation (or symptoms) is often present and exacerbations are often unpredictable events, mostly related to viral infections [31,32]. Secondly, normal lung function (under treatment) is the rule in asthmatic children $[15,17]$ and a "phenotype » of children exhibiting a decline in lung function is almost impossible to isolate [17]. Thirdly, therapeutic compliance (and inability to use the inhaler properly) in children may be difficult to obtain [33] that may further explain the presence of mild symptoms.

\section{Usefulness of $\mathrm{FENO}_{0.05}$ measurement}

We confirm by our first statistical approach that $\mathrm{FE}_{\mathrm{NO}}$ is linked to its classical modifiers such as height and atopy. The link with ICS dose is more controversial, but we previously evidenced such a link with a plateau effect of ICS[6]. We show that exhaled NO and bronchodilator response are linked, a result that was previously obtained by different research groups[2,3,9]. More interestingly, we demonstrate for the first time that the relationships between exhaled NO and both ICS dose (an indirect marker of airway inflammation) and bronchodilator response (a marker of airway tonus) are independent. Exhaled NO measurement is claimed to be an allergic inflammometer, but it is also a marker of airway smooth muscle tone[34].

The recent study of Dweik and colleagues has shown that a high $\mathrm{FE}_{\mathrm{NO}}$ "phenotype" $\left(\mathrm{FE}_{\mathrm{NO} 0.05}>35 \mathrm{ppb}\right)$ was characterized by greatest airway reactivity, airflow limitation, hyperinflation, sputum eosinophilia and levels of symptoms[9]. Consequently, our results (first statistical approach) are in agreement with their data, but we further suggest that $\mathrm{FE}_{\mathrm{NO}}$ is not specifically associated with a clinically relevant phenotype in asthmatic children. Haldar and colleagues elegantly demonstrated that eosinophilic inflammation helps to characterize adult asthma phenotypes[22]. Consequently our results may seem at variance, but exhaled NO and airway eosinophilia could be discordant in childhood[14]. In summary, to our best knowledge, this is the first study in childhood asthma, showing that exhaled NO does help to describe a clinically useful phenotype despite its ability to describe underlying pathophysiology (inflammation and modified airway smooth muscle function).

\section{Limitations of the study}

Principal among these is the cluster analysis methodology. The use of an algorithm that separates the population into discrete clusters may not be realistic. The limited size of our out-hospital population, the restricted analysis of childhood asthma (that could be a more homogeneous disease per se), our choice of clustering parameters and the loss of clinical material through attrition of the data set may have introduced some bias, but we hypothesized that the clinical relevance of exhaled NO should be "easily" demonstrated. It has to be stated that, in a cross-sectional design mainly assessing asthma control, FENO0.05 was not associated with a specific cluster, which is in accordance with recent trials failing to demonstrate the clinical usefulness of this measure for asthma control[35].

\section{Perspectives}

It has to be emphasized that, in a cross-sectional design mainly assessing asthma control, $\mathrm{FENO}_{0.05}$ was not associated with a specific cluster, which is in accordance with recent trials failing to demonstrate the clinical usefulness of this measure for asthma control[35]. Whether peripheral airway/alveolar NO concentration after correction for axial NO back-diffusion, which is elevated in a subset of asthmatic patients $(\sim 25 \%)$, could help to identify a specific "phenotype" of asthma warrants further studies[4,36,37].

In conclusion, $\mathrm{FENO}_{0.05}$ is independently linked to two pathophysiological characteristics of childhood asthma (ICS-dependant inflammation and bronchomotor tone) but does not help to identify a clinically relevant phenotype of asthmatic children in a cross-sectional analysis of routinely recorded parameters.

\section{Author details}

${ }^{1}$ Cabinet La Berma, 4 avenue de la Providence; 92160 Antony, France. ${ }^{2}$ Assistance Publique-Hôpitaux de Paris; Hôpital Européen Georges Pompidou; Service de Physiologie - Clinique de la Dyspnée, Paris, France. ${ }^{3}$ Mosquito respiratory research group, Paris, France. ${ }^{4}$ University Paris Descartes, Paris, France. ${ }^{5} \mathrm{ClC} 9201$ Plurithématique, Hôpital Européen Georges Pompidou, Paris, France.

\section{Authors' contributions}

BM carried out the measurements, participated in the design of the study and drafted the manuscript. SP performed the statistical analysis and helped to draft the manuscript. CD2 conceived of the study, participated in its design and helped to draft the manuscript. All authors read and approved the final manuscript.

\section{Competing interests}

The authors declare that they have no competing interests.

Received: 4 March 2011 Accepted: 20 May 2011 Published: 20 May 2011

\section{References}

1. Mahut B, Delclaux C, Tillie-Leblond I, Gosset P, Delacourt C, ZerahLancner F, Harf A, de Blic J: Both inflammation and remodeling influence nitric oxide output in children with refractory asthma. J Allergy Clin Immunol 2004, 113(2):252-256.

2. Mahut B, Trinquart L, Bokov P, Peiffer C, Delclaux C: The link between exhaled NO and bronchomotor tone depends on the dose of inhaled steroid in asthma. Respir Med 2010, 104(7):945-50.

3. Puckett JL, Taylor RW, Leu SY, Guijon OL, Aledia AS, Galant SP, George SC: An elevated bronchodilator response predicts large airway inflammation in mild asthma. Pediatr Pulmonol 2010, 45(2):174-181.

4. Mahut B, Trinquart L, Le Bourgeois M, Becquemin MH, Beydon N, Aubourg F, Jala M, Bidaud-Chevalier B, Dinh-Xuan AT, Randrianarivelo O, et al: Multicentre trial evaluating alveolar NO fraction as a marker of asthma control and severity. Allergy 2010, 65(5):636-644. 
5. Mahut B, Delacourt C, Zerah-Lancner F, De Blic J, Harf A, Delclaux C: Increase in alveolar nitric oxide in the presence of symptoms in childhood asthma. Chest 2004, 125(3):1012-1018.

6. Mahut B, Peiffer C, Thibaudon M, Chevalier-Bidaud B, Defrance-Hutinet MF, Trinquart $L$, Delclaux C: What does a single exhaled nitric oxide measurement tell us in asthmatic children? J Asthma 2009, 46(8):810-814.

7. Laoudi Y, Nikasinovic L, Sahraoui F, Grimfeld A, Momas I, Just J: Passive smoking is a major determinant of exhaled nitric oxide levels in allergic asthmatic children. Allergy 2010, 65(4):491-497.

8. Delclaux C, Mahut B, Zerah-Lancner F, Delacourt C, Laoud S, Cherqui D, Duvoux C, Mallat A, Harf A: Increased nitric oxide output from alveolar origin during liver cirrhosis versus bronchial source during asthma. Am J Respir Crit Care Med 2002, 165(3):332-337.

9. Dweik RA, Sorkness RL, Wenzel S, Hammel J, Curran-Everett D, Comhair SA, Bleecker E, Busse W, Calhoun WJ, Castro M, et al: Use of exhaled nitric oxide measurement to identify a reactive, at-risk phenotype among patients with asthma. Am J Respir Crit Care Med 2010, 181(10):1033-1041.

10. Han MK, Agusti A, Calverley PM, Celli BR, Criner G, Curtis JL, Fabbri LM, Goldin JG, Jones PW, Macnee W, et al: Chronic obstructive pulmonary disease phenotypes: the future of COPD. Am J Respir Crit Care Med 2010, 182(5):598-604.

11. The Global Initiative for Asthma (GINA). 2007 [http://www.ginasthma. com], (accessed on october, 2nd 2010).

12. Reddel HK, Taylor DR, Bateman ED, Boulet LP, Boushey HA, Busse WW, Casale TB, Chanez P, Enright PL, Gibson PG, et al: An official American Thoracic Society/European Respiratory Society statement: asthma control and exacerbations: standardizing endpoints for clinical asthma trials and clinical practice. Am J Respir Crit Care Med 2009, 180(1):59-99.

13. Mahut B, Peiffer C, Bokov P, Delclaux C, Beydon N: Use of specific airway resistance to assess bronchodilator response in children. Respirology 2011, 16(4):666-671.

14. Bush A, Saglani S: Management of severe asthma in children. Lancet 2010 376(9743):814-825.

15. Mahut B, Bokov P, Delclaux C: Abnormalities of plethysmographic lung volumes in asthmatic children. Respir Med 2010, 104(7):966-971.

16. Mahut B, Peiffer C, Bokov P, Beydon N, Delclaux C: Gas trapping is associated with severe exacerbation in asthmatic children. Respir Med 2010, 104(8):1230-1233.

17. Mahut B, Trinquart L, Bokov P, Peiffer C, Delclaux C: Lung Function Impairment Evidenced by Sequential Specific Airway Resistance in Childhood Persistent Asthma: A Longitudinal Study. J Asthma 2010, 47(6):655-9.

18. ATS/ERS recommendations for standardized procedures for the online and offline measurement of exhaled lower respiratory nitric oxide and nasal nitric oxide, 2005. Am J Respir Crit Care Med 2005, 171(8):912-930.

19. Mahut B, Trinquart $L$, Bokov $P$, Peiffer $C$, Delclaux $C$ : The link between exhaled NO and bronchomotor tone depends on the dose of inhaled steroid in asthma. Respir Med 2010, 104(7):945-950.

20. Zapletal A, Samanek M: [Flow resistance of airways and pulmonary flow resistance in children and juveniles. Normal values and their significance for the evaluation of airway obstruction]. Cesk Pediatr 1977, 32(9):513-522.

21. Quanjer PH, Borsboom GJ, Kivastik J, Merkus PJ, Hankinson JL, Houthuijs D, Brunekreef B, Ihorst G, Kuhr J: Cross-sectional and longitudinal spirometry in children and adolescents: interpretative strategies. Am J Respir Crit Care Med 2008, 178(12):1262-1270.

22. Haldar P, Pavord ID, Shaw DE, Berry MA, Thomas M, Brightling CE Wardlaw AJ, Green RH: Cluster analysis and clinical asthma phenotypes. Am J Respir Crit Care Med 2008, 178(3):218-224.

23. Kaiser $\mathrm{H}$ : The varimax criterion for analytic rotation in factor analysis. Psychometrika 1958, 23:187-200.

24. Hartigan JA, Wong MA: Algorithm AS 136: a K-means clustering algorithm. Appl Stat 1978, 28:100-108.

25. Ding C, He X: K-means Clustering via Principal Component Analysis. Proc of Int'l Conf Machine Learning (ICML 2004): 2004 2004, 225-232.

26. de Blic J, Boucot I, Pribil C, Robert J, Huas D, Marquet C: Control of asthma in children: still unacceptable? A French cross-sectional study. Respir Med 2009, 103(9):1383-1391.

27. Schleich FN, Seidel L, Sele J, Manise M, Quaedvlieg V, Michils A, Louis R: Exhaled nitric oxide thresholds associated with a sputum eosinophil count $>=3 \%$ in a cohort of unselected patients with asthma. Thorax 2010, 65(12):1039-1044.
28. Merkus PJ, Borsboom GJ, Van Pelt W, Schrader PC, Van Houwelingen HC, Kerrebijn KF, Quanjer PH: Growth of airways and air spaces in teenagers is related to sex but not to symptoms. J Appl Physiol 1993, 75(5):2045-2053

29. Litonjua AA, Sparrow D, Weiss ST: The FEF25-75/FVC ratio is associated with methacholine airway responsiveness. The normative aging study. Am J Respir Crit Care Med 1999, 159(5 Pt 1):1574-1579.

30. Sharma S, Litonjua AA, Tantisira KG, Fuhlbrigge AL, Szefler SJ, Strunk RC, Zeiger RS, Murphy AJ, Weiss ST: Clinical predictors and outcomes of consistent bronchodilator response in the childhood asthma management program. J Allergy Clin Immunol 2008, 122(5):921-928 e924.

31. Mahut $B$, Refabert $L$, Marchac $V$, Iniguez JL, Aubertin $G$, Tamalet $A$, Lebras MN, Troadec C, Chatellier G, Delclaux C: Influenza-like illness responsible for severe exacerbations in asthmatic children during $\mathrm{H} 1 \mathrm{~N} 1$ pandemic: a survey before vaccination. J Asthma 2011, 48(3):224-227.

32. Mahut $B$, Trinquart $L$, Delclaux $C$ : Influence of age on the risk of severe exacerbation and asthma control in childhood. J Asthma 2011, 48(1):65-68.

33. Megas F, Benmedjahed K, Lefrancois G, Mueser M, Dusser D: [The "Compli'Asthme" therapeutic observation survey on good use of inhaled drugs for asthma: perception by general practitioners]. Rev Pneumol Clin 2004, 60(3):158-165.

34. Tadie JM, Henno P, Leroy I, Danel C, Naline E, Faisy C, Riquet M, Levy M, Israel-Biet D, Delclaux C: Role of nitric oxide synthase/arginase balance in bronchial reactivity in patients with chronic obstructive pulmonary disease. Am J Physiol Lung Cell Mol Physiol 2008, 294(3):489-497.

35. Petsky HL, Cates CJ, Li A, Kynaston JA, Turner C, Chang AB: Tailored interventions based on exhaled nitric oxide versus clinical symptoms for asthma in children and adults. Cochrane Database Syst Rev 2009, , 4: CD006340.

36. Mahut B, Delclaux C: Peripheral airway/alveolar nitric oxide concentration in asthma. Thorax 2010, E-pub Alert.

37. Puckett JL, Taylor RW, Leu SY, Guijon OL, Aledia AS, Galant SP, George SC: Clinical patterns in asthma based on proximal and distal airway nitric oxide categories. Respir Res 2010, 11:47.

doi:10.1186/1465-9921-12-65

Cite this article as: Mahut et al:: Exhaled nitric oxide and clinical

phenotypes of childhood asthma. Respiratory Research 2011 12:65.

\section{Submit your next manuscript to BioMed Central and take full advantage of:}

- Convenient online submission

- Thorough peer review

- No space constraints or color figure charges

- Immediate publication on acceptance

- Inclusion in PubMed, CAS, Scopus and Google Scholar

- Research which is freely available for redistribution

Submit your manuscript at www.biomedcentral.com/submit
C Biomed Central 